\title{
EVEKTIVITAS PENGUNAAN MODEL LATIHAN OLAHRAGA PERNAPASAN MONACORS UNTUK PEMELIHARAAN KESEHATAN FUNGSI PARUBAGI MAHASISWA DALAM MENGHADAPI PANDEMI COVID-19
}

\author{
${ }^{1)}$ Yohanes Bayo Ola Tapo, ${ }^{2)}$ Robertus Lili Bile \\ Dosen Prodi PJKR STKIP Citra Bakti \\ email: yohanesbayoolatao@gmail.com, robertulilibile16@gmail.com.
}

\begin{abstract}
Abstrak
Tren pandemi covid-19 yang berdampak pada kebijakan new normal mengharuskan berbagai pola protokol kesehatan diantaranya menjaga jarak aman minimal 2 meter dan tidak berkerumunan, hal ini kemudian berdampak pada pembatasan berbagai aktivitas mahasiswa dalam dunia pendidikan yangmenyebabkan mahasiswa tidak dapat melaksanakan rutinitas olahraga seperti biasaguna menjaga derajat kesehatan dan kebugaran tubuh. Penelitian ini bertujuan untuk menguji efektivitas penggunaan model latihan olahraga pernapasan monacors untuk pemeliharaan kesehatan fungsi paru mahasiswa selama pandemi covid-19. Penelitian ini dilaksanakan pada Mahasiswa Prodi PJKR STKIP Citra Bakti Ngada dengan melibatkan mahasiswa sebanyak 16 orang sebagai sampel. Penelitian ini menggunakan desainpraeksperimen time series dengan rancangan one group pretest-posttest. Data penelitian dikumpulkan melalui tes dan pengukuran arus puncak ekspirasi (APE) sebagai indikator kesehatan fungsi paru. Teknik analisis data yang digunakan adalah statistik nonparametrik uji beda wilcoxon signed ranks test, dengan hasil uji nilai Sig. (2-tailed) $\mathrm{APE}=(0,000<0,05)$, sehingga dapat disimpulkan bahwa terdapat pengaruh penggunaan model latihan olahraga pernapasan monacors untuk pemeliharaan kesehatan fungsi paru ditinjau dari perubahan rata-rata nilai arus puncak ekspirasi ke arah kategori normal. Denga demikian dapat disimpulkan bahwa model latihan olahraga pernapasan monacors efektif digunakan untuk pemeliharaan kesehatan fungsi parubagi mahasiswa selama pandemi covid-19.
\end{abstract}

Kata kunci: Efektivitas Model Monacors, Olahraga Pernapasan, Kesehatan Fungsi Paru.

\begin{abstract}
This study aims to test the effectiveness of using a monacors breathing exercise model to maintain the health of student lung function during the Covid-19 pandemic. This research was conducted on 16 students of PJKR STKIP Citra Bakti Ngada as a sample. This study used a time series pre-experimental design with a one-group pretest-posttest design. The research data were collected through tests and measurement of peak expiratory flow (APE) as an indicator of lung function health. The data analysis technique used is the nonparametric statistical difference test Wilcoxon signed ranks test, with the Sig. $(2$-tailed) APE $=(0.000<0.05)$ so that there is an effect of using a monacors breathing exercise model for health maintenance of lung function in terms of changes in the average value of the peak expiratory flow to the normal category. So it can be concluded that the monacors breathing exercise model is effective for the maintenance of lung function health for students during the Covid-19 pandemic.
\end{abstract}

Kata kunci: Effectiveness of Monacors Model, Breathing Exercise, Lung Function Health. 


\section{PENDAHULUAN}

Kesehatan merupakan kebutuhan yang penting dan memegang peranan utama dalam keberlangsungan dan kualitas hidup manusia, karena kesehatan adalah aspek utama dari komponen kualitas hidup manusia, yaitu komponen physical being yang merupakan komponen kualitas hidup yang memandang individu sebagai dirinya, meliputi: kesehatan fisik termasuk gizi dan kebugaran yang berkaitan dengan mobilitas fisik dan kelincahan serta kebersihan pribadi dan perawatan (Renwick \& Brown, 1996).

Undang-Undang Kesehatan No. 23 Tahun 1992 (Undang-Undang RI, 1992), menyebutkan bahwa kesehatan adalah keadaan sejahtera dari badan, jiwa, dan sosial yang memungkinkan setiap orang hidup produktif secara sosial dan ekonomis. Batasan ini dapat dilihat sebagai perwujudan kesehatan yang merupakan satu kesatuan utuh dari berbagai komponen kesehatan, yaitu: sehat fisik, sehat mental, sehat sosial dan sehat spiritual, yang saling berhubungan dan saling mempengaruhi sehinga pada akhirnya individu dapat dikatakan sehat secara total.

Berdasarkan kajian di atas dapat kita katakan bahwa aspek kesehatan fisik merupakan aspek utama dalam pemenuhan kesehatan total, sebab aspek kesehatan fisik dapat berpengaruh secara langsung pada aspek kesehatan lainnya,dengan kesehatan fisik yang baik maka pengembangan pada aspek kesehatan mental, kesehatan sosial dan kesehatan spiritual dapat dilaksanakan dengan lebih efektif.Secara teoretis, kesehatan fisik atau juga disebut kebugaran fisik memiliki kontribusi vital sebagai indikator status kesehatan seseorang secara menyeluruh. Kebugaran fisik dalam batasan yang sederhana dapat dipahami sebagai sebuah kondisi dimana tubuh dapat melakukan semua tugas gerak baik dalam pekerjaan sehari-hari maupun latihan atau aktivitas olahraga secara optimal dan tidak mengalami kelelahan yang berlebihan serta terhindar dari resiko gangguan kesehatan (Bile, 2019:31). Hal ini mengindikasikan bahwa, selain dapat melakukan tugas gerak secara optimal, seseorang dengan kebugaran fisik yang baik akan dapat meminimalisir resiko mengalami berbagai gangguan kesehatan sebagai implikasi dari rendahnya tingkat kebugaran jasmani.Selanjutnya Tapo (2020: 40) menyimpulkan bahwa batasan kebugaran jasmani dalam menjalankan kehidupan adalah sebagai kemampuan atau keadaan fisikdalam menjalankan berbagai aktivitas kerja sehari-hariatau tugas gerak yang berat dalamwaktu yang relatif lama tanpamengalami kelelahan berlebih, dan masihmemiliki cadangan tenaga untukmelakukan aktivitas fisik lainnyadengan waktuistirahat yang singkat.

Kasus gangguan kesehatan fisik yang cukup banyak ditemui di masyarakat salah satunya adalah gangguan sistem pernapasan (respirasi). Menurut Kemenkes Republik Indonesia (2015: 1) menyebutkan bahwa menurut laporan Organisasi Kesehatan Dunia (WHO) dalam World Health Report 2000, lima penyakit paru merupakan penyebab utama $(17,4 \%)$ dari seluruh kematian di dunia. Gangguan pada sistem 
pernapasan berdampak pada gangguan sistem kardiorespirasi, yang merupakan kemampuan sistem kerja jantung, paru dan pembuluh darah untuk berfungsi secara optimal pada keadaan istirahat dan keadaan kerja dalam mengambil oksigen dan menyalurkannya ke jaringan yang aktif sehingga dapat digunakan pada proses metabolisme tubuh (Depkes Republik Indonesia, 1999).

Kenyataan ini menempatkan gangguan kesehatan pernapasan perlu mendapatkan perhatian khusus. Ditinjau dari fungsi fisiologi tubuh manusia, gangguan atau penyakit sistem pernapasan merupakan penyakit yang menyerang organ-organ pernapasan dan/atau saluran pernapasan seperti gangguan pada kerja jantung, fungsi paru, penyempitan saluran napas, dan penyempitan pembuluh darah yang dapat membawa dampak pada sistem homeostasis fisiologis tubuh yang tidak normal, karena kurangnya ketersediaan pasokan oksigen $\left(\mathrm{O}_{2}\right)$ yang cukup pada organ-organ tubuh untuk menjalankan fungsi metabolismenya

Virus corona diketahui merupakan virus yang secara langsung menyerang fungsi paru dalam mencukupi kebutuhan oksigen $\left(\mathrm{O}_{2}\right)$ sehingga penderita akan mengalami kekurangan oksigen $\left(\mathrm{O}_{2}\right)$.

Putri (2020: 705) menjelaskan pendapat Tosepu (2020) bahwa tanda dan gejala umum infeksicovid-19 termasukgejala gangguanpernapasan akut seperti demam, batuk,dan sesak napas. Masa inkubasi rata-rata adalah 5 - 6hari dengan masainkubasi demam, batuk, dan sesaknapas. Pada kasus yang parah, covid-19 dapatmenyebabkan pneumonia, sindrom pernapasan akut,gagal ginjal, dan bahkan kematian. Selanjutnya Putri (2020: 706) menjelaskan bahwa: salah satulangkah awal yang dilakukan oleh pemerintah yaitumensosialisasikan gerakan SocialDistancing untukmasyarakat. Langkahini bertujuan untuk memutus matarantai penularan pandemi covid-19 inikarena langkahtersebut

mengharuskanmasyarakat menjaga jarak amandengan manusia lainnya minimal 2 meter, tidakmelakukan kontaklangsung dengan orang lain sertamenghindari pertemuan massal, seperti yang dikutip dari (Buana D.R: 2020).

Keadaan yang disampaikan di atas menggambarkan keadaan pandemi covid-19 berdampak ke berbagai hal kebijakan new normal mengharuskan berbagai pola protokol kesehatan diantaranya menjaga jarak aman minimal 2meter dan tidakberkerumunan, hal ini kemudian berdampak juga pada pembatasan berbagai aktivitas mahasiswa dalam dunia pendidikan yang menyebabkan mahasiswa tidak dapat melaksanakan rutinitas olahraga seperti biasa guna menjaga derajat kesehatan dan kebugaran tubuh.

Giriwijoyo \& Sidik (2013: 41-43), menjelaskan bahwa kesehatan sistem pernapasan memiliki pengaruh yang besar pada sehat fisik secara umum, karena pada dasarnya manusia adalah makhluk aerobik yang berarti kehidupan manusia sangat bergantung pada kebutuhan oksigen $\left(\mathrm{O}_{2}\right)$ untuk menjalankan segala fungsi sel tubuhnya. 
Pelaksanaan upaya kesehatan melalui kegiatan olahraga dapat dilakukan dengan olahraga kesehatan dalam bentuk latihan fisik (olahraga konvensional) dan olahraga kesehatan dalam bentuk latihan pernapasan (olahraga pernapasan). Kedua bentuk olahraga kesehatan ini sama-sama dapat memberikan manfaat pada kesehatan melalui proses adaptasi kemampuan tubuh, karena adanya rangsangan berupa respon latihan yang berulang yang dapat dicapai dengan sebuah kondisi pelatihan pada saat melakukan aktivitas olahraga. Giriwijoyo \& Sidik (2013: 43), kondisi pelatihan adalah kesenjangan antara kebutuhan atau tuntutan akan $\mathrm{O}_{2}$ dengan pasokannya; artinya pasokan tidak dapat memenuhi tuntutannya, karena besar tuntutan melebihi kemampuan memasoknya.

Olahraga konvensional dengan pernapasan bebas yang diatur secara reflektorik, kesenjangan dapat terjadi karena meningkatnya intensitas olahraga sehingga kebutuhan akan $\mathrm{O}_{2}$ lebih besar dari kemampuan memasok $\mathrm{O}_{2}$, sedangkan pada olahraga pernapasan kesenjangan terjadi dengan cara mengendalikan pasokan $\mathrm{O}_{2}$ sehingga terjadi kesenjangan kebutuhan akan $\mathrm{O}_{2}$ dan tuntutan pengeluaran $\mathrm{CO}_{2}$ dari dalam tubuh. Kedua bentuk kondisi pelatihan atau kesenjangan ini akan memberikan respon latihan pada tubuh dalam bentuk kekurangan oksigen yang disebut hutang oksigen (hipoksia) dan kelebihan karbondioksida yang disebut hiperkapnia (hiperkarbia). Kondisi hipoksia $\mathrm{O}_{2}$ dan hiperkapnia $\mathrm{CO}_{2}$ yang terjadi akibat aktivitas latihan dapat merangsang berbagai sistem kerja dalam tubuh mulai dari sistem saraf (simpatik dan parasimpatik), sistem kardiorespirasi sampai sistem kerja tubuh secara umum untuk dapat bekerja secara lebih maksimal.

Giriwijoyo\& Sidik (2013: 45), menjelaskan bahwa pada olahraga pernapasan fungsi sistem pernapasan sebagai gerbang masuknya $\mathrm{O}_{2}$ akan dikendalikan dan menyebabkan ventilasi (pertukaran udara) menjadi terhambat dan akhirnya kandungan $\mathrm{O}_{2}$ di dalam paru dan darah menjadi rendah, sehingga pasokan $\mathrm{O}_{2}$ ke sel-sel tubuh, otot dan fungsi tubuh secara keseluruhan baik yang aktif maupun yang tidak aktif akan mengalami respon latihan berupa kekurangan $\mathrm{O}_{2}$ (hipoksia oksigen).

Pengaruh perubahan yang terjadi pada arus puncak ekspirasi akibat perlakuan latihan menggunakan model latihan olahraga pernapasan, karena terjadi perubahan pada kemampuan organ dan saluran pernapasan sebagai bentuk dari adaptasi terhadap intensitas latihan yang secara langsung memberikan kondisi pelatihan dalam bentuk pengelolaan oksigen oleh organ dan saluran napas selama proses latihan dengan cara mengendalikan masuknya oksigen untuk menciptakan keadaan kekurangan (hipoksia) oksigen. Organ pernapasan paru-paru, otot interkostal dan diafragma mendapatkan berbagai rangsangan dan pelatihan sehingga mampu mengembangkan kemampuan inspirasi dan ekspirasi dalam menyediakan dan menggunakan oksigen lebih maksimal, yang dibuktikan dengan meningkatkannya arus puncak ekspirasi sebagai salah satu indikator 
kesehatan atau fungsi paru dan sistem pernapasan.

Solomen \& Aaron (2015: 237), menjelaskan bahwa latihan pernapasan dapat meningkatkan volume paru, membersihkan sekresi, memperbaiki pertukaran gas, mengendalikan sesak napas, meningkatkan kapasitas olahraga, mengurangi tekanan darah, mengurangi obesitas, respons relaksasi untuk mengurangi stres dan mengendalikan rasa sakit pada kelahiran normal. Latihan pernapasan dengan penekanan pada latihan inspirasi akan meningkatkan kapasitas volume paru-paru, dan penekanan pada latihan ekspirasi dapat membantu membersihkan sekresi dari saluran napas.

Gunjal, et al(2015: 238) menjelaskan penelitian Shravya yang menemukan bahwa dengan melakukan 10 menit latihan pernapasan yang dalam dan pelan (6 pernapasan/menit) berpengaruh pada fungsi paru, hasil penelitian membuktikan bahwa efek langsung latihan pernapasan dalam dan pelan menunjukkan peningkatan yang signifikan pada FVC, $\mathrm{FEV}_{1}$, PEFR.

Gunjal, et al, (2015: 237) menjelaskan temuan penelitian bahwa latihan pernapasan segmental (per bagian) dapat meningkatkan ekspansi dada dan paru, disebabkan karena latihan pernapasan dengan relaksasi interkostal yang cepat saat ekspirasi akan menyebabkan fasilitasi (mempermudah) kontraksi interkostal saat inspirasi sehingga perluasan dada dan paru-paru akan meningkat.

Ravi \&Swamy (2013: 74), menjelaskan bahwa dengan latihan pernapasan yang teratur pusat pernafasan di medula oblongata dapat diatur sesuai kehendak. Pada saat melakukan latihan pernapasan yang dalam, seseorang secara sadar terus menerus melakukan fase inspirasi yang dalam dan kuat sehingga paru-paru dan dinding alveoli dapat meluas dan merentang secara maksimal, sehingga meningkatkan penyesuaian rongga dada.

Latihan pernapasan yang dalam menyebabkan durasi inspirasi meningkat secara bertahap yang menyebabkan pusat pernapasan secara bertahap akan melakukan penyesuaian untuk menahan peningkatan $\mathrm{PCO}_{2}$ dari pada $\mathrm{PO}_{2}$, sehingga walaupun $\mathrm{PCO}_{2}$ merangsang kemoreseptor yang terletak di medula oblongata mengirim implus ke sistem pusat pernapasan untuk melakukan proses ekspirasi, namun implus untuk melakukan ekspirasi tidak kuat melawan kehendak dari korteks akibat meningkatnya kemampuan sistem pusat pernapasan menahan $\mathrm{PCO}_{2}$. Selain itu peningkatan perkembangan otot pernafasan dan daya tahan tubuh akibat latihan pernapasan dalam yang teratur dapat menunda timbulnya kelelahan (Ravi \&Swamy, 2013: 74).

$$
\text { Model latihan olahraga }
$$
perampasan "Monacors" merupakan model latihan olahraga pernapasan yang dikembangkan oleh Tapo (2017) menggunakan beberapa teknik pernapasan De Colores yang kemudian teknik-teknik ini dikembangkan dengan cara digabungkan, dikurangi, dan dimodifikasi, sehingga menghasilkan sebuah model latihan olahraga pernapasan yang baik, layak dan efektif digunakan untuk pemeliharaan kesehatan. Model latihan olahraga 
pernapasan Monacors, terdiri dari 6 bentuk latihan pernapasan (Teknik Pernapasan Diam 1 sampai 6)yang dilakukan secara diam (ditempat) dan bentuk latihan pernapasan sambil melakukan rangkaian 8 bentuk gerakan (Tapo, 2017: 177 - 200).

Model latihan olahraga Monacors ini digunakan sebagai sebuah model latihan olahraga pernapasan bagi mahasiswa/i PJKR STKIP Citra Bakti Ngada guna menggantikan rutinitas aktivitas olahraga konvensional yang tidak dapat dilaksanakan selama masa pandemi covid-19, sehingga sampel diarahkan untuk melakukan aktivitas latihan sesuai dengan ketentuan dan pedoman olahraga pernapasan Monacors.

\section{METODOLOGI PENELITIAN}

Penelitian ini menggunakan desain penelitian pra-eksperimen time series dengan rancangan penelitianone group pretest-posttest. Sampel penelitian diberikan perlakuan dengan penggunaan model latihan olahraga pernapasan monacors selama 3 seri latihan dalam 3 minggu (3 kali latihan dalam seminggu), kemudian dilakukan tes fungsi paru dengan ukuran drajat kesehatan fungsi paru yang dipakai dalam penelitian in adalah indikator Arus Puncak Ekspirasi (APE) yang diukur (dites) menggunakan peak flow metersehingga secara keseluruhan adalah:

Jumlah perlakuan latihan sebanyak 9 kali, yaitu:

a) 3 kali perlakuan pada minggu pertama $\left(X_{1}\right)$,

b) 3 kali perlakuan pada minggu kedua $\left(\mathrm{X}_{2}\right)$, dan

c) 3 kali perlakuan pada minggu ketiga $\left(X_{3}\right)$.

Jumlah pengukuran arus puncak ekspirasi dilakukan sebanyak 4 kali, yaitu:

a) pengukuran awal (pretest) sebelum perlakuan $\left(\mathrm{O}_{1}\right)$,

b) pengukuran seri pertama setelah perlakuanminggu pertama $\left(\mathrm{O}_{2}\right)$,

c) pengukuran seri kedua setelah perlakuanminggu kedua $\left(\mathrm{O}_{3}\right)$, dan

d) pengukuran seri ketiga setelah perlakuan minggu ketiga $\left(\mathrm{O}_{4}\right)$.

\section{HASIL DAN PEMBAHASAN}

Berdasarkan hasil pengukuran arus puncak ekspirasi (APE) sebagai indikator fungsi paru, adapun hasil dari pengukuran awal $\left(\mathrm{O}_{1}\right)$, pengukuran seri pertama $\left(\mathrm{O}_{2}\right)$, pengukuran seri kedua $\left(\mathrm{O}_{3}\right)$, dan pengukuran seri Ketiga $\left(\mathrm{O}_{4}\right)$, seperti pada Tabel 1.

Tabel 1. Deskripsi Data Uji Arus Puncak Ekspirasi

\begin{tabular}{|c|c|c|c|c|}
\hline \multirow{2}{*}{ Kategori } & \multicolumn{2}{|c|}{ Subjek } & \multicolumn{2}{|c|}{ APE } \\
\hline & $\mathbf{n}$ & $\%$ & $\Sigma$ & $\bar{X} \pm \mathrm{SD}$ \\
\hline \multicolumn{5}{|c|}{ Pengukuran Pretest $\left(\mathrm{O}_{1}\right)$} \\
\hline Normal & 5 & 31.3 & 2680 & $536.0 \pm 63.0$ \\
\hline Kurang` & 11 & 68.8 & 5680 & $516.4 \pm 62.7$ \\
\hline Jumlah & 16 & 100 & 8360 & $522.5 \pm 61.3$ \\
\hline \multicolumn{5}{|c|}{ Pengukuran Seri Pertama Minggu Pertama $\left(\mathrm{O}_{2}\right)$} \\
\hline
\end{tabular}




\begin{tabular}{|l|c|c|c|c|}
\hline \multirow{2}{*}{ Kategori } & \multicolumn{2}{|c|}{ Subjek } & \multicolumn{2}{c|}{ APE } \\
\cline { 2 - 5 } & $\mathbf{n}$ & $\%$ & $\Sigma$ & $\bar{X} \pm$ SD \\
\hline Normal & 8 & 50 & 4500 & $562.5 \pm 56.5$ \\
Kurang $^{\prime}$ & 8 & 50 & 4190 & $523.8 \pm 68.9$ \\
Jumlah & $\mathbf{1 6}$ & $\mathbf{1 0 0}$ & $\mathbf{8 6 9 0}$ & $\mathbf{5 4 3 . 1 \pm 6 4 . 1}$ \\
\hline
\end{tabular}

\begin{tabular}{|c|c|c|c|c|}
\hline \multicolumn{5}{|c|}{ Pengukuran Seri Kedua Minggu Kedua $\left(\mathrm{O}_{3}\right)$} \\
\hline Vormal & 12 & 75 & 6840 & $570.0 \pm 53.3$ \\
\hline Kurang` & 4 & 25 & 2050 & $5 \pm 78.5$ \\
\hline Jumlah & 16 & 100 & 8890 & $555.6 \pm 63.0$ \\
\hline \multicolumn{5}{|c|}{ Pengukuran Seri Ketiga Minggu Ketiga $\left(\mathrm{O}_{4}\right)$} \\
\hline ormal & 15 & 920 & 8700 & $580.0 \pm 54.9$ \\
\hline 'urang & 1 & 6. & 45 & $450.0 \pm-$ \\
\hline Jumlah & 16 & 100 & 9150 & $571.9 \pm 62.2$ \\
\hline
\end{tabular}

Berdasarkan Tabel 1, hasil pengukuran Arus Puncak Ekspirasi dari pengukuran awal sampai pengukuranseri ketiga dapat dijelaskan sebagai berikut.

\section{Perubahan}

\section{Berdasarkan}

\section{Kategori Subjek:}

a) Perlakuan seri pertama minggu pertama $\left(X_{1}\right)$ :

(1) Jumlah subjek pada kategoriNormal $=5$ orang $(31,3 \%)$ naik menjadi 8 orang $(50,0 \%)$,

(2) Jumlah subjek pada kategori Kurang $=11$ orang $(68,8 \%)$ turun menjadi 8 orang $(50,0 \%)$,

(3) perbedaan selisih sebanyak 3 orang $(18,8 \%)$ antara pretest $\left(\mathrm{O}_{1}\right)$ dan posttest seri pertama minggu pertama $\left(\mathrm{O}_{2}\right)$.

b) Perlakuan seri kedua minggu kedua $\left(\mathrm{X}_{2}\right)$ :

(1) Jumlah subjek pada kategoriNormal $=8$ orang $(50,0 \%)$ naik menjadi 12 orang $(75,0 \%)$,
(2) Jumlah subjek pada kategori Kurang $=8$ orang $(50,0 \%)$ turun menjadi 4 orang $(25,0 \%)$,

(3) perbedaan selisih sebanyak 4 orang $(25,0 \%)$ antara posttest seri pertama minggu pertama $\left(\mathrm{O}_{2}\right)$ dan posttest seri kedua minggu kedua $\left(\mathrm{O}_{3}\right)$.

c) Perlakuan seri ketiga minggu ketiga $\left(\mathrm{X}_{3}\right)$ :

(1) Jumlah subjek pada kategoriNormal $=12$ orang $(75,0 \%)$ naik menjadi 15 orang $(93,8 \%)$,

(2) Jumlah subjek pada kategori Kurang $=4$ orang $(25,0 \%)$ turun menjadi 1 orang $(6,3 \%)$,

(3) perbedaan selisih sebanyak 3 orang $(18,8 \%)$ antara posttest seri kedua minggu kedua $\left(\mathrm{O}_{3}\right)$ dan posttest seri ketiga minggu ketiga $\left(\mathrm{O}_{4}\right)$.

Sehingga perubahan antara pretest $\left(\mathrm{O}_{1}\right)$ dan posttest seri ketiga minggu ketiga $\left(\mathrm{O}_{4}\right)$ : 
(1) Jumlah subjek pada kategoriNormal $=5$ orang $(31,3 \%)$ naik menjadi 15 orang $(93,8 \%)$,

(2) Jumlah subjek pada kategori Kurang $=11$ orang $(25,0 \%)$ turun menjadi 1 orang $(6,3 \%)$,

(3) perbedaan selisih sebanyak 10 orang $(62,5 \%)$ antara pretest $\left(\mathrm{O}_{1}\right)$ dan posttest seri ketiga minggu ketiga $\left(\mathrm{O}_{4}\right)$.

2. Perubahan Berdasarkan RataRata Arus Puncak Ekspirasi:

a) Perlakuan seri pertama minggu pertama $\left(X_{1}\right)$ - perubahan antara pretest $\left(O_{1}\right)$ dan posttest seri pertama minggu pertama $\left(\mathrm{O}_{2}\right)$ :

(1) Rata-rataAPE pada kategori Normal $=(536.0$ liter $/$ menit $)$ menjadi $\quad=(562.5$ kali/menit)dengan selisih peningkatan $=(26,5$ liter/menit),

(2) Rata-rataAPE pada kategori Kurang $=(516.4$ liter $/$ menit $)$ menjadi $\quad=\quad(523.8$ kali/menit)dengan selisih peningkatan $=(7,4 \mathrm{kali} /$ menit $)$,

(3) Rata-rata APE secara klasikal dari (522.5 kali/menit) menjadi (543.1 liter/menit) dengan selisih peningkatan $=(20,6$ liter/menit).

b) Perlakuan seri kedua minggu kedua $\left(\mathrm{X}_{2}\right)$ - Perubahan antara posttest seri pertama minggu pertama $\left(\mathrm{O}_{2}\right)$ dan posttest seri kedua minggu kedua $\left(\mathrm{O}_{3}\right)$ :

(1) Rata-rataAPE pada kategori Normal $=(562,5$ liter $/$ menit $)$ menjadi $\quad=(570,0$ liter/menit)dengan selisih peningkatan $=(7,5$ liter $/$ menit $)$,

(2) Rata-rataAPE pada kategori Kurang $=(523.8$ liter $/$ menit $)$ menjadi $\quad=\quad(512.5$ kali/menit)dengan selisih penurunan $=(11,3$ liter/menit $)$,

(3) Rata-rata APE secara klasikal dari (543.1 liter/menit) menjadi (555.6 kali/menit) dengan selisih peningkatan $=(12,5$ liter/menit).

c) Perlakuan seri ketiga minggu ketiga $\left(\mathrm{X}_{3}\right)$ - Perubahan antara posttest seri kedua minggu kedua $\left(\mathrm{O}_{3}\right)$ dan posttest seri ketiga minggu ketiga $\left(\mathrm{O}_{4}\right)$ :

(1) Rata-rataAPE pada kategori Normal $=(570.0$ liter $/$ menit $)$ menjadi $\quad=\quad(580.0$ liter/menit)dengan selisih peningkatan $=(10,0$ liter/menit),

(2) Rata-rataAPE pada kategori Kurang $=(512.5$ liter $/$ menit $)$ menjadi $=(450,0$ liter $/$ menit $)$ denganselisih penurunan = (62,5 kali/menit),

(3) Rata-rata APE secara klasikal dari (555,6 liter/menit) menjadi (571,9 liter/menit) dengan selisih peningkatan $=(16,3$ liter/menit).

Sehingga Perubahan antara pretest $\left(\mathrm{O}_{1}\right)$ dan posttest seri ketiga minggu ketiga $\left(\mathrm{O}_{4}\right)$ :

(1) Rata-rataAPE pada kategori Normal $=(536.0 \quad$ liter $/$ menit $)$ menjadi $=(580.0$ liter $/$ menit $)$ dengan selisih peningkatan $=(44,0$ liter/menit),

(2) Rata-rataAPE pada kategori Kurang $=(516.4$ liter $/$ menit $)$ menjadi $=(450.0$ liter $/$ menit $)$ dengan selisih penurunan $=(66,4$ liter/menit),

(3) Rata-rata APE secara klasikal dari (522.5 liter/menit) menjadi (571.9 liter/menit) dengan selisih peningkatan $=(49,4$ liter $/$ menit $)$.

Selanjutnya data hasil pengukuran Arus Puncak Ekspirasi (APE) dianalisis menggunakan analisis statistik uji beda 
antara data pretest $\left(\mathrm{O}_{1}\right)$ dengan data posttest seri ketiga minggu ketiga $\left(\mathrm{O}_{4}\right)$ dengan tahapan sebagai berikut.

\section{Uji Persyaratan Analisis}

Uji normalitas menggunakan Uji Shapiro-Wilk, sedangkan uji homogenitas tidak dibuat karena desain penelitian menggunakan one group pretest-posttest design dengan analisis statistik uji beda yang dilakukan pada data pretest dan posttest sampel berpasangan, sehingga subjek penelitian berasal dari kelompok yang sama. Adapun hasil uji normalitas data seperti pada Tabel 2.

Tabel 2. Output Uji Normalitas Shapiro-Wilk Arus Puncak Ekspirasi

Tests of Normality

\begin{tabular}{|c|c|c|c|c|c|c|}
\hline & \multicolumn{3}{|c|}{ Kolmogorov-Smirnov ${ }^{\mathrm{a}}$} & \multicolumn{3}{c|}{ Shapiro-Wilk } \\
\cline { 2 - 7 } & Statistic & $\mathrm{df}$ & Sig. & Statistic & $\mathrm{df}$ & Sig. \\
\hline $\begin{array}{c}\text { Pretest Arus Puncak } \\
\begin{array}{c}\text { Ekspirasi } \\
\text { Posttest Arus Puncak } \\
\text { Ekspirasi }\end{array}\end{array}$ & .236 & 16 & .017 & .872 & 16 & .030 \\
\hline
\end{tabular}

Berdasarkan perhitungan pada Tabel 2, dapat dilihat bahwa nilai sig. (2-tailed) pretest $\left(\mathrm{O}_{1}\right)$ dan posttest $\left(\mathrm{O}_{4}\right)$ untuk arus puncak ekspirasi $=(0,030)$ dan $(0,032)$, jadi secara keseluruhan $(p<$ $0,05)$ sehingga data berdistribusi "Tidak Normal".

2. Uji Analisis Statistik

Data pretest $\left(\mathrm{O}_{1}\right)$ dan data posttest seri ketiga minggu ketiga $\left(\mathrm{O}_{4}\right)$ untuk arus puncak ekspirasi berdistribusi tidak normal, sehingga harus menggunakan analisis statistik non parametrikuji beda dengan uji wilcoxon signed ranks testmenggunakan aplikasi IBM SPSS Statistics 22 dengan syarat uji adalah: Jika ( $p<0,05)$, maka terdapat perbedaan yang signifikan antara data pretest dan posttest, sehingga ada pengaruh penggunaan model terhadap kesehatan fungsi paru. Adapun hasil uji beda dengan uji wilcoxon signed ranks test seperti pada Tabel

Tabel 3. Output Uji Wilcoxon Signed Ranks Test Arus Puncak Ekspirasi

Test Statistics Wilcoxon Signed Ranks Test

\begin{tabular}{|c|c|}
\hline & $\begin{array}{c}\text { Posttest - Pretest } \\
\text { Arus Puncak Ekspirasi }\end{array}$ \\
\hline Z & $-3.526^{\mathrm{b}}$ \\
Asymp. Sig. (2-tailed) & .000 \\
\hline
\end{tabular}

Berdasarkan perhitungan pada

Tabel 3, dilihat bahwa Sig. (2-tailed) pretest dan posttest arus puncak ekspirasi $=(\mathbf{0 , 0 0 0})$, sehingga secara keseluruhan $(p<0,05)$. Berdasarkan perhitungan ini disimpulkan bahwa terdapat perbedaan yang signifikan antara data pretest dan posttest, sehingga terdapat pengaruh pemberian perlakukan dengan model latihan olahraga pernapasan monacors terhadap perubahan arus puncak ekspirasi ke arah kategori normal.

Berdasarkan hasil pengukuran pada seri terakhir perlakukan terdapat 15 orang $(93,8 \%)$ subjek berada pada 
kategori "Normal" dengan rata-rata arus puncak ekspirasi $=(580,0$ liter $/$ menit $)$ BerdasarkanKetentuan Norma Arus Puncak Ekspirasi(APE) sesuai dengan jenis kelamin, umur dan tinggi badan subjek, maka model latihan olahraga pernapasan "Monacors"dapat dikatakan sangat "Efektif" untuk pemeliharaan kesehatan fungsi paru mahasiswa PJKR selama pandemi covid-19 sebagai pengganti rutinitas olahraga konvensional yang tidak dapat dilaksanakan selama pembatasan protokol kesehatan covid - 19 .

Hal ini dibuktikan dengan adanya perubahan pada seri-seri perlakuanpengukuranArus Puncak Ekspirasi sebagai indikator kesehatan fungi paru yang selalu berubah ke arah normal, dan sejauh perlakuan yang diberikan tidak terdapat subjek penelitian pada kategori normal yang berubah ke arah kategori kurang.

Perubahan-perubahan sebagai hasil dari latihan menggunakan model latihan olahraga Monacors, terjadi karena adanya kondisi pelatihan (kesenjangan kebutuhan akan $\mathrm{O}_{2}$ dan tuntutan pengeluaran $\mathrm{CO}_{2}$ dari dalam tubuh) dari aktivitas latihan pada olahraga pernapasan yang dapat memberikan respon latihan pada tubuh dalam bentuk kekurangan oksigen yang disebut hutang oksigen (hipoksia) dan kelebihan karbondioksida yang disebut hiperkapnia (hiperkarbia). Kondisi hipoksia $\mathrm{O}_{2}$ dan hiperkapnia $\mathrm{CO}_{2}$ yang terjadi akibat aktivitas latihan dapat merangsang berbagai sistem kerja dalam tubuh mulai dari sistem saraf (simpatik dan parasimpatik), sistem kardiorespirasi sampai sistem kerja tubuh secara umum untuk dapat bekerja secara lebih maksimal.
Temuan penelitian menunjukkan terjadinya perubahan yang signifikan pada fungsi paru berdasarkan indikator arus puncak ekspirasi. Perubahan pada arus puncak ekspirasi yang sangat signifikan ini dapat terjadi karena proses latihan pernapasan yang dilakukan secara langsung memberikan pelatihan dan efek pada paru-paru sehingga dapat berfungsi lebih baik karena dalam pelatihan terus dirangsang untuk dapat bekerja secara maksimal dalam menyediakan kebutuhan oksigen.

Perubahan-perubahan yang terjadi dapat dilihat dari dua bentuk perubahan, yaitu: perubahan secara langsung pada organ atau alat dan saluran pernapasan karena latihan pernapasan secara langsung berkenaan dengan sistem pernapasan, sehingga terjadi berbagai kondisi pelatihan pada sistem pernapasan yang secara bertahap akan menyebabkan adaptasi kemampuan organ atau alat dan saluran pernapasan untuk dapat bekerja secara lebih maksimal. Perubahan yang lain terjadi secara menyeluruh akibat keadaan yang ditimbulkan karena proses latihan pernapasan dalam bentuk kekurangan oksigen. Hal ini sangat memberikan respon latihan pada sebagian besar fungsi tubuh, yang pada akhirnya menyebabkan terjadinya berbagai adaptasi fungsi tubuh untuk dapat lebih bekerja secara maksimal.

\section{SARAN}

Sesuai dengan hasil dan temuan dalam penelitian ini, Model latihan olahraga pernapasan "monacors" terbukti efektif untuk pemeliharaan kesehatan fungsi 
paru, sehingga peneliti menyarankan kepada semua pihak untuk dapat mencoba menggunakan model latihan olahraga Monacors sebagai salah satu aktivitas olahraga guna menggantikan rutinitas olahraga konvensional dalam rangka menghadapi pandemi covid-19 guna menjaga kesehatan fungsi paru yang menjadi salah satu fungsi utama tubuh. 


\section{DAFTAR PUSTAKA}

Bile, R.L. \& Suharjana (2019). Efektivitas Penggunaan Model Latihan Kebugaran "BBC Exercise"Untuk PemeliharaanKebugaran Jasmani Mahasiswa. Journal of Physical Education, Sport and Recreation.Volume 3 Nomor 1 September 2019.

Depkes Republik Indonesia. (1999). Rencana Pembangunan Kesehatan Menuju Indonesia Sehat 2010. Jakarta.

Giriwijoyo, H.Y.S.S., \& Sidik, D.Z. (2013). Ilmu Kesehatan Olahraga. Bandung: Remaja Rosdakarya.

Gunjal, S. B., Shinde, N.K., Kazi, A.H., et al. (2015). Effectiveness of Deep Breathing Versus Segmental Breathing Exercises on Chest Expansion in Pleural Effusion. International Journal of Health Sciences and Research, Vol.5, 413-736.

Kemenkes Republik Indonesia (2015).You Can Control Your Asthma. Jakarta: Pusat Data dan Informasi Kementerian Kesehatan RI (Info Datin).

Putri, R. N. (2020). Indonesia dalam Menghadapi Pandemi Covid-19. Jurnal IImiah Universitas Batanghari Jambi. 20 (2), Juli 2020, DOI 10.33087/jiubj.v20i2.1010.

Ravi, G.N., \& Narasimha, S.K.N. (2013). Effect of Deep Breathing on Pulmonary Functions in Healthy Young Individuals. Journal of Evolution of Medical and Dental Sciences, Vol 2, 6072-6079.

Renwick, R., \& Brown, I. (1996). Quality of Life in Health Promotion and Rehabilitation. California. Sage Publication, Inc.

Solomen, S., \& Aaron, P. (2015). Breathing Techniques - A Review. International Journal of Physical Education, Sports and Health, 2 (2): 237-241.

Tapo, Y, B, O (2017).Pengembangan Model Latihan Olahraga Pernapasan Untuk Pemeliharaan Kesehatan Kardiorespirasi. (S2 thesis versi cetak,UNY).

Tapo, Y, B, O (2017). Evaluasi Status Kebugaran Jasmani Dan Tingkat Penguasaan Keterampilan Olahraga Sepakbola Dan Bola Voli Mahasiswa Pjkr Semester V Stkip Citra Bakti Ngada Berdasarkan Aktivitas Perkuliahan Praktek Dan Pembinaan Kegiatan UKM. EJURNAL IMEDTECH(Instructional Media, Design and Technology).Vol.4, No.1, Juni 2020. 